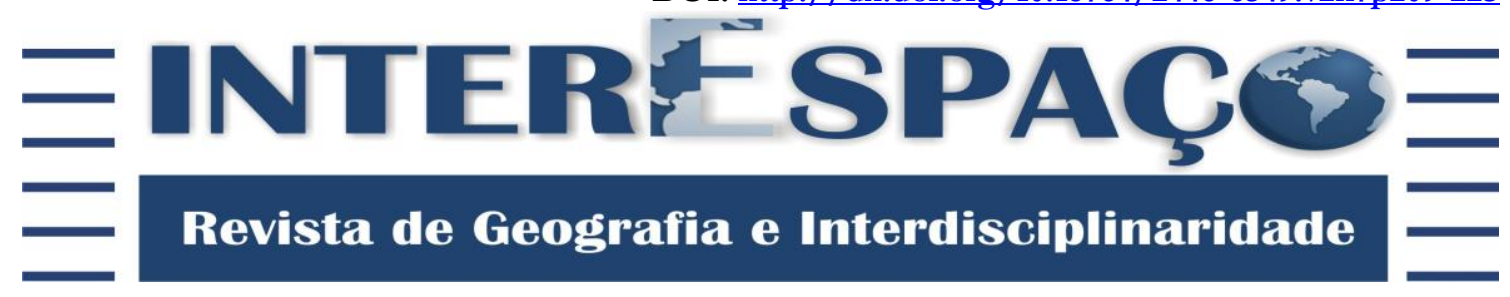

\title{
“A UTOPIA DE UM CORPO INCORPÓREO”: Corpo, poder e saber em Michel de Foucault
}

\author{
Assis Daniel Gomes \\ Historiador e Filósofo. Doutorando em História Social pela Universidade Federal do Ceará - UFC. \\ historiaassis47@yahoo.com
}

\begin{abstract}
RESUMO
Neste trabalho buscamos refletir, de forma bem introdutória, sobre algumas inquietações levantadas por Michel Foucault, especialmente o que chama de disciplinalização e utopia do corpo. Inferimos que essas são influenciadas pela filosofia pós-Sartriana, envolvidas pelos afetos decorrentes de maio de 1968 e de um retorno à filosofia de Nietzsche. Esse filósofo da transgressão questiona os pressupostos até então colocados pela filosofia de vertente marxista, vinculada ao conceito de luta de classe e ao papel militante do intelectual (Sartre), para se pensar o corpo e o poder. Enfim, Foucault reflete como se constrói certa sociedade disciplinar, como dadas convenções mutila o corpo, inventa-o e domina-o através de determinados interesses permeados por relações de micropoder.
\end{abstract}

Palavras-chave: Corpo; Poder-saber; Michel de Foucault.

\section{"UTOPIA OF AN INTANGIBLE BODY": Corps, power and knowledge in Michel Foucault}

\section{ABSTRACT}

In this paper we reflect, well introductory way, about some concerns raised by Michel Foucault, especially what he calls body utopia and disciplinary. We infer that these are influenced by post-Sartrean philosophy, involved the affections resulting from May 1968 and a return to the philosophy of Nietzsche. This philosopher of transgression questions the assumptions hitherto posed by philosophy Marxist perspective, linked to the concept of class struggle and militant intellectual role (Sartre), to think about the body and power. Finally, Foucault reflects how to build certain disciplinary society, as given conventions cripples the body, invents it and mastered it through certain interests permeated by relations of micro-power.

Keywords: Body; Power-knowledge; Michel Foucault.

\section{"UTOPÍA DE UN CUERPO INTANGIBLE":} El cuerpo, el poder y el conocimiento en Michel Foucault

\footnotetext{
RESUMEN

En este trabajo se reflexiona, de manera bien introductoria, acerca de algunas preocupaciones planteadas por Michel Foucault, en especial lo que él llama disciplinalization y utopía del cuerpo. Deducimos que estos están influenciados por la filosofía post-sartreana, participan las afecciones resultantes a partir de mayo de 1968 y un retorno a la filosofía de Nietzsche. Este filósofo de la transgresión en tela de juicio los supuestos hasta ahora planteados por la filosofía perspectiva marxista,
} 
“A utopia de um corpo incorpóreo": corpo, poder e saber em Michel de Foucault Assis Daniel Gomes

vinculadas al concepto de lucha de clases y militante función intelectual (Sartre), que pensar en el cuerpo y el poder. Por último, Foucault refleja cómo construir cierta sociedad disciplinaria, según las convenciones dadas paraliza el cuerpo, inventa y dominado por ciertos intereses permeadas por relaciones de micro-poder.

Palabras clave: Cuerpo; El Poder-saber; Michel Foucault.

\section{INTRODUÇÃO}

Neste artigo, propomos refletir sobre o pensamento do filósofo Michel de Foucault, especificamente algumas de suas proposições que correlacionam os estudos sobre o corpo e a sua relação com a produção de saber-poder. Para isso, demarcamos rapidamente alguns autores que contribuíram para a construção de sua filosofia. Colocá-los se faz pertinente para demonstrar a complexidade de seu pensamento e a impossibilidade de abordarmos essas contribuições em profundidade. No intuito de mapear como esse autor olhou para o corpo, fê-lo seu objeto de análise e estudo, buscando operacionalizá-lo e transmutá-lo, almejamos propor questões em torno de uma dada "ontologia do presente". Portanto, iniciamos nosso itinerário percorrendo o contexto histórico em que o seu pensamento surge, não como forma de enquadrá-lo em alguma perspectiva da época, mas verificar seus fluxos, dispersões e invenções.

O mundo vive após a Segunda Guerra Mundial uma tensão entre as duas potências do momento, a saber, os Estados Unidos da América (EUA) e a União das Repúblicas Socialistas Soviéticas (URSS). O cotidiano desses países se torna incerto, a imagem de progresso advinda pela pregação de seus governantes, baseada pelas ideias da Revolução Francesa e do Iluminismo, destrói-se a cada morte, atentado e explosão que deixaram marcada e, segundo Foucault, inscrita no corpo essas sequelas modificadoras do campo de percepção dos intelectuais europeus, por exemplo. Dessa forma, as consequências advindas do pós-1945 promoveram não apenas uma destruição econômica de alguns países europeus, mas de sua imagem como um continente movido pela razão e pelos valores cristãos. Os questionamentos se fazem concernente às possibilidades promovidas pela ciência e tecnologia, que não estavam sendo usadas para promover o bem coletivo, como alguns pensadores afirmam, porém manejadas como mecanismos de poder geopolítico em proporções globais.

Dentre as inquietações socioculturais colocadas à época, destacamos o de Emmanuel Kant e de Auguste Comte. Esses dois sistemas de pensamento não são somente

\footnotetext{
1 Conforme Adverse, a "ontologia do presente" foucaultiana é uma investigação histórica por meio dos
} eventos, através de seu olhar genealógico e de seu método arqueológico. 
“A utopia de um corpo incorpóreo": corpo, poder e saber em Michel de Foucault

criticados por Foucault, mas contribuem para a construção de seu pensamento. Em relação ao primeiro, destacamos a força que seu sistema tinha naquele momento, como também possui em nosso presente, para se pensar uma filosofia transcendental. Para isso, através da construção de três obras (Crítica da Razão Pura, Crítica da Razão Prática, Crítica do Juízo) caminha por vários campos da análise filosófica, defendendo traços de um conhecimento metafísico que não pensa apenas em si, contudo move-se para si e o em si - para si, acarretando práticas, elementos morais e éticos, políticos e estéticos.

As formulações kantianas partem do pensamento iluminista e procuram definir com maior precisão o que os pensadores de sua época disseram sobre a sua defesa. A sua tentativa é defini-la em meio às pluralidades de conceitos e posições que em sua maioria são conflitantes e imprecisas. Portanto, pós-1945 a imagem soberana e civilizada da Europa se coloca em cotejo, critica-se os princípios fundamentais do iluminismo. Isso emana depois das Guerras Mundiais com a perda de alguns valores defendidos pelo Iluminismo, por exemplo, de que a humanidade consegue a emancipação do homem através da razão, da ciência. Tal expectativa se frustra ao verificar que em vez de prosperidade, vê-se morte, invasões e o desrespeito à dignidade das famílias e dos sujeitos que a compunham, ao se olhar para a encarnação da busca pelo poder visualizada pelas lágrimas e imagens impactantes dos campos de concentração nazifascista.

A Sociedade Ocidental que defende os valores da liberdade, fraternidade e igualdade, que se coloca como movida pela racionalidade e ciência, como civilizada e civilizadora de outros povos e culturas, naquele momento entra em uma crise de percepções, quebras de expectativas e frustrações provenientes de sua experiência nesses confrontos bélicos vivenciados no século XX.

Para Kant, em seu artigo feito em 1784, "Resposta a pergunta: O que é o iluminismo?", define a palavra Iluminismo, que se assenta pelos seus contemporâneos, entretanto sem precisão de balizas racionais que a fundamentasse. Para ele, essa palavra se transforma em um conceito, que carrega em seu significado desejos e projeções de cunho teleológico para quem o procurasse realizar. Dessa forma, o iluminismo se torna um projeto e uma missão. Emmanuel Kant busca, então, sistematizar um sentido para essa palavra que demarca um tempo, que propagaria um modelo racional e formas de experiências, como também as experimentações vivenciadas pelos intelectuais que a defendiam no século XVIII, como Voltaire e Rousseau.

O iluminismo é um estado, conforme Kant, enquanto tal é movimento e processo em busca de sua efetivação como ato. Portanto, a posição de buscá-lo deve ser realizada 
por todos os homens. Assim, é esse estado de busca que o caracteriza e dá sustentação para novas atitudes e ações, o iluminismo é esse processo em que o homem ainda não o é, mas está caminhando para ser, para luz, para a libertação da sua inocência pela razão. Fazer, então, parte desse processo o permite sair de um estágio de menoridade para a maioridade, da dependência à emancipação. Essa ênfase na racionalidade, enquanto meio de emancipação da humanidade e seu instrumento, elege-se como uma forma de mover o desejo de construir sua soberania, levá-la a um crescimento social e econômico pautado pelos princípios da autonomia emancipadora da razão. Para esse filósofo, o iluminismo é a "saída do homem da sua menoridade de que ele próprio é culpado. A menoridade é a incapacidade de se servir do entendimento sem a orientação de outrem [...]" (KANT, A481, 3 dez de 1783, p. 516) e que sua palavra de ordem é esta: "Tem a coragem de te servires do teu próprio entendimento!” (KANT, A481, 3 dez. 1783, p. 516).

Esse discurso emancipador da razão o coloca no XVIII como força maior de transformação, como elemento poderoso de intervenção na vida das pessoas, que não desejam se submeter ao pensamento religioso cristão, buscam outras diretrizes de reger e orientar a sua vida. Esse desejo de poder, em que a troca se fez do sobrenatural, representado pelo Deus Cristão, para os caminhos traçados por um sistema racional, passa a ser criticado quando se busca também valorizar um conhecimento mais empírico, que buscasse descobrir certa verdade e intervir na vida das pessoas de uma forma visível. $\mathrm{Na}$ procura de encontrar leis que regem o mundo natural, no anseio de dominá-las para conseguir fornecer aos homens respostas sobre algumas questões colocadas, cuja razão não dá respostas convincentes, constroem-se métodos que aliam procedimentos racionais e estudos experimentais buscando positivar suas descobertas tendo em vista uma emancipação pela ciência. No século XIX, Comte (1978) defende a Ciência Positiva, buscando aproximar as ciências humanas, procura certa imutabilidade social, que o ajuda a explicar a sociedade, mas também a dá elementos para a sua intervenção, ao pensá-la num concatenamento de leis físico-sociais. Tal perspectiva se embasa pelo ideal de construir por seus meios uma humanidade de progresso e bonança. Esse pensador de forma sistemática, por conseguinte, constrói hipóteses que demarcam fases em que a sociedade deve passar. Para ele, são estas: a teológica, a filosófica e a positiva.

A primeira se move pelo conhecimento cosmológico ou teológico de ver o mundo e intervir nele, a segunda a razão se sobressai como forma de saber em relação às crenças e à fé. Contudo, para ele, dar valor a metafísica não possibilita empreender efetivamente mudanças materiais na vida cotidiana da sociedade, ficando essa transformação no mundo 
das ideias, nas categorias axiológicas e em pressuposições hipotético-dedutivas carregadas de sentido em si mesmas. Já a última, tem a junção desse a priori com o a posteriori, da ideia com a experiência, que movimenta uma modificação positiva, "efetiva" e "real". Para ele, "circunscreve seus esforços ao dominio, que agora progride rapidamente da verdadeira observação, única base possível de conhecimentos verdadeiramente acessíveis, sabiamente adaptados a nossas necessidades reais" (COMTE, 1978, p. 48, grifos nossos).

A ciência social, então, é, para ele, um saber determinado por esse mover racionalexperimental. Contudo, ainda a razão se torna soberana - utilizada, por sua vez, como meio de construir algo concreto que promovesse alterações maciças. Enquanto um pensamento burguês, o positivismo Comtiano, visa à manutenção do status quo, elege uma classe que domina, coloca-a como condutora das demais e usufruidora de boa parte das transformações promovidas pela a fase positiva. Para corroborar tal afirmativa, esse pensador compara a física orgânica com a construção de uma física social, enfatizando a busca de leis que regem esse sistema-organismo. Para Comte (1978, p. 50, grifos nossos), "nas leis dos fenômenos consiste realmente a ciência, à qual os fatos propriamente ditos em que pese a sua exatidão e a seu número, não fornecem mais do que os materiais indispensáveis".

Pós-1945 essas ideias postuladas acima começam a ser mais firmemente combatidas e o marxismo, como ideologia e embasamento científico, é utilizado especialmente pelas Humanidades nesse intento. Nesse cenário, a filosofia de Jean-Paul Sartre, defensor desse paradigma, aponta-se como nome de maior influência na cena intelectual e acadêmica europeia. Esse filósofo tem duas concepções que balizam e se fazem presentes em sua obra e militância, são estas: 1- o ser humano é sujeito de suas ações; 2- a liberdade é condicionada pelo momento histórico (SARTRE, 1978). Consoante Foucault, a ideia de intelectual e o papel do sujeito estão vinculados. Consoante Eribon (1990, p. 195),

A partir de 1969 Foucault começa a encarnar a própria figura do intelectual militante. Nesse momento se inventa o Foucault que todo o mundo conhece, das manifestações e dos manifestos, das "lutas" e da "crítica", às quais a cátedra do Collége de France confere uma solidez e uma força ainda maiores.

A partir desse momento, Foucault pensa, diferentemente de Sartre, o sujeito e o papel do intelectual na sociedade. Para o referido pensador, tal sujeito não dá mais conselho, não busca edificar um projeto de salvação da humanidade, apenas fornece "os instrumentos de análise, e é este hoje, essencialmente, o papel do historiador" (FOUCAULT, 1975, p. 05). Essa outra maneira de pensá-lo em meio à enfática soberania da filosofia marxista é possível por sua retomada do pensamento de Nietzsche. Nesse 
“A utopia de um corpo incorpóreo": corpo, poder e saber em Michel de Foucault Assis Daniel Gomes

sentido, alguns pressupostos nietzschianos que impactam esses pensadores e sua nova forma de ver o mundo e filosofar sobre ele, por exemplo, são estes: 1- o sujeito é uma transfiguração temporária de impulsos; 2- o constante processo de permanência do ser humano; 3- todo infrator e criador (NIETZSCHE, 1999).

Outros autores também são importantes para o seu pensamento, como Heidegger. Para Veyne (2011), Foucault é influenciado por ele, especialmente em seu sentimento de devir e das descontinuidades. A partir disso, enfim, discorreremos o pensamento transgressor e infrator produzido por Michel de Foucault sobre o corpo - como objeto de saber-poder.

\section{E O OUTRO?}

O elemento transgressor no pensamento de Foucault, por exemplo, promove quebras com o postulado de pensar o poder em uma postura marxista, em que burguesia domina o proletariado e explora a sua força de trabalho, retirando-o a mais-valia. Nessa relação em que o corpo do trabalhador é disciplinado pela dominação de seu trabalho, ela se dá de forma estática e unilateral. O poder nessa perspectiva se move muito mais pela força econômica como promovedor das relações sociais. Para Foucault, os mecanismos de poder estão em suas microrrelações. Esse, por sua vez, é pulverizado, dá-se pela sutileza do cotidiano e se move por uma relação bilateral. Para Williams (2013, p. 159),

\footnotetext{
O papel da transgressão é descobrir as fendas na rede do poder ou, nas palavras de Foucault, criar um labirinto em que podemos nos perder e nos tornar algo diferente. Ele descreve "para não ter mais um rosto" (AK: 19), porque o rosto identidade - é uma criação da história e parte da influência que ela tem sobre nós. Através de nossos "rostos" o poder opera em nós e fixa os padrões sob os quais podemos nos mover.
}

Poder e saber se imbricam a partir do século XVII como uma forma de produzir um conhecimento que gere elementos de dominação da natureza, sejam eles físicos, como também os chamados do "espírito". Os traços da normalização racional, elementos que disciplinam e controlam os sujeitos com dispositivos manejados pela sociedade em prol de marcar uma dominação sutil e em que a força bruta se utiliza como último recurso de certa imposição. Para ele, o poder o produz, institui disciplinas que o controla, que o movimenta para os caminhos arquitetados por quem o exerce, ou seja, é "a partir de um poder sobre o corpo que foi possível um saber fisiológico, orgânico” (FOUCAULT, 1975, p. 03). 
“A utopia de um corpo incorpóreo": corpo, poder e saber em Michel de Foucault Assis Daniel Gomes

Portanto, como as linhas das teias das aranhas e na fragmentação diferencial das nuvens que surgem e destroem-se no céu, da mesma maneira a sociedade é uma fabricação, uma criação, um mudar-se em que se liga por teias restantes no arrastar de resquícios e formas antigas. Ela é normatizada por discursos que constroem disciplinamentos para assegurar grupos, modelos e posturas. Ao tratar de forma específica à sexualidade, enquanto, construção sócio-histórica, Foucault busca verificar nesse processo a docilidade do discurso disciplinador que atinge os sujeitos em sua vida hodierna e em seus gestos mais corriqueiros. Tais discursos procuram afirmar valores, naturalizá-los e edificar modelos de sexualidade através de uma pedagogia de que o diferente do padrão é patológico. Para isso, conforme Foucault, vários discursos são movimentados para corroborar com essa fabricação, para dar-lhe visibilidade. Consoante ele, é importante observar que ao analisar as histórias se podem verificar os micropoderes, os micros discursos e as suas sutilezas de engendramento a partir do XVII.

\begin{abstract}
Seu caráter minúsculos: que o cotidiano da sexualidade aldeão, os ínfimos deleites campestres tenha podido tornar-se, a partir de um certo momento, o objeto não somente de uma intolerância coletiva, mas de uma ação judiciária, de uma intervenção médica, de um atento exame clínico e de toda uma elaboração teórica. O importante está em que dessa personagem comum, até então parte integrante da vida camponesa, se tenha tentado medir a caixa craniana, estudar a ossatura facial e inspecionar a anatomia, na busca de possíveis sinais de degenerescência; que o fizessem falar; que o interrogassem sobre seus pensamentos, gostos, hábitos, sensações, juízos (FOUCAULT, 1999, p. 33).
\end{abstract}

É, portanto, nessas minúcias dos discursos que os dispositivos de afirmação de valores, normas e modelos sociais ganham solidez. O Ocidente, diferente do Oriente, cunha uma Ciência do Sexo, e ao criá-la, segundo Foucault, acaba realizando um forjamento de instrumentos que na vida diária das pessoas controlam seus corpos. A racionalidade científica se almeja através das estratégias justificadas pelo "cuidado do corpo", em dominar sua animalidade e torná-lo mais dócil. No século XIX o imperativo do discurso da higiene se destaca dentro dessas ciências reguladoras, que tem estes princípios, segundo esse filósofo: 1 - buscar pela eficácia física; 2- procurar pela pureza moral do corpo social. Nessa mesma época o controle populacional é balizado também pela produção de um saber-poder sobre o sexo/corpo a partir da biologia, o conhecimento da reprodução dos seres humanos, e da medicina do sexo.

Conforme ele, no século XVIII se constrói a partir de quatro principais conjuntos certos dispositivos de assujeitamento do corpo e da sexualidade através da produção de um saber-poder, a saber, são os seguintes: "histerização do corpo da mulher"; "pedagogização 
do sexo da criança"; "socialização das condutas de procriação"; "psiquiatrização do prazer perverso". A preocupação com o sexo faz produzir sutilezas disciplinares para dominar o que alguns chamam a "animalidade" do corpo, ou seja,

\footnotetext{
$\mathrm{Na}$ preocupação com o sexo, que aumenta ao longo de todo o século XIX, quatro figuras se esboçam como objetos privilegiados de saber, alvos e pontos de fixação dos empreendimentos do saber: a mulher histérica, a criança masturbadora, o casal malthusiano, o adulto perverso, cada uma correlativa de uma dessas estratégias que de formas diversas, percorrem e utilizaram o sexo das crianças, das mulheres e dos homens (FOUCAULT, 1999, p. 100).
}

Para Foucault (1999, p. 101), a relação entre o dispositivo da aliança, "sistema de matrimônio, de fixação e desenvolvimento dos parentescos, de transmissão dos nomes e dos bens", e da sexualidade, dá-se de forma correlacional, mas levando em conta as suas devidas peculiaridades, ou seja, se antes é o primeiro que cria o segundo, dando-lhes sustentabilidade, consoante esse filósofo, essa relação se inverte, pois a naturalização da sexualidade acaba legitimando o dispositivo da aliança: "para o primeiro, o que é pertinente é o vinculo entre parceiros com status definido; para o segundo, são as sensações do corpo, a qualidade dos prazeres, a natureza das impressões, por tênues ou imperceptíveis que sejam" (FOUCAULT, 1999, p. 101).

Foucault, a partir disso, pensa o corpo e a sexualidade em suas relações econômicas, ou seja, o corpo enquanto produtor e consumidor. É essa especificidade do dispositivo de sexualidade com o corpo que constrói e se ordena pela "homeostase do corpo social, a qual é sua função manter, daí seu vínculo privilegiado com o direito" (FOUCAULT, 1999, p. 101). Ele, então, deriva da história e da cultura da sociedade que o fabrica, por se transmutar e modificar-se nela própria o dispositivo de sexualidade "tem, como razão de ser, não o reproduzir, mas o proliferar, inovar, anexar, inventar, penetrar nos corpos de maneira cada vez mais detalhada e controlar as populações de modo mais global" (FOUCAULT, 1999, p. 101).

Em sua obra Vigiar e Punir, Foucault elege uma parte para discutir sobre os "Corpos dóceis". No início de seu primeiro parágrafo analisa a diferença existente entre a figura do soldado no século XVII e XVIII. Neste o corpo dele, em seus componentes físicos e subjetivos, é fabricado, assenhoreado por dispositivos sociais que lhes buscam dar determinadas características e silenciar aquelas consideradas impróprias para a sua visibilidade, aquele figura a sua idealização utilizando estas imagens de afirmação: 1- o reconhecimento de uma tradição; 2- ser possuidor de sinais naturais que caracterizam: vigor e coragem; 3- marcas de orgulho. O corpo nessa concepção se coloca como representante 
de um brasão, é a sua própria personificação e o instrumento de propaganda da instituição que defende, por isso deve transmitir a força e a valentia, sinais positivos para essa vocação no século XVII; em contraponto a partir do XVIII o seu status muda para uma busca profissional. Tal transformação transpunha-a de uma determinação transcendental, cujo assentamento é inquestionável, para uma habilidade, uma escolha do sujeito em desenvolver certa atividade que possibilite uma renda para a manutenção de sua família.

Para Foucault (2009), à época clássica descobre o corpo enquanto um objeto que se elege alvo principal de poder, à época moderna o redescobre dando novos sentidos e atribuindo-lhes novas maneiras de dominação. Isso se tem em vista que o cuidado do corpo e seu assenhoreamento, feito pelos gregos e romanos, não tinham passado pelas várias inovações no campo do conhecimento e pelo impacto da filosofia patrística e escolástica no cotidiano europeu. Portanto, começa-se a se desenhar um retorno aos clássicos antigos no XVII, buscando traços de seu pensamento que ajudasse a romper com a dominação religiosa nas várias áreas da vida europeia, como a política e a econômica. A construção de um diferente ao posto, feita pelos pensadores renascentistas a partir do século XIV e sua radicalização com os iluministas (XVIII), não descarta o campo visual em que são criados, ou seja, as marcas do pensamento teológico que movia os rumos de seus territórios, mas também tomam atitudes de mudá-los, transgredi-los e miná-los em seu interior.

Portanto, o corpo é elemento do discurso anatômico-metafísico e técnico-político, de submissão e utilização. Esses dois registros são distintos enquanto "funcionamento e explicação" de um corpo útil e inteligível (FOUCAULT, 2009, p. 71). Essa relação de fabricação do corpo se acopla com a noção de docilidade em duas posições não binárias, mas em sua correlação: analisável e manipulável. Conforme esse filósofo, "em qualquer sociedade, o corpo está preso no interior de poderes muito apertados, que lhe impõem limitações, proibições ou obrigações" (FOUCAULT, 2009, p. 71).

O corpo nessa fabricação é feito pela sutileza do detalhe que disciplina e modela. Os seus símbolos de forças são mais fortes do que a sua expressividade física, a sua atuação e controle se torna muito mais exaustiva e eficaz, "a disciplina é uma anatomia política do detalhe" (FOUCAULT, 2009, p. 72). O medo da repressão simboliza o poder do repressor muito mais do que a manutenção desesperada de seu poder por meio da violência, isso, contudo representa a fragilidade e a crise de suas forças legitimadoras de certas dominações. É, por isso, nessa micropolítica e micropoder, vivido e mantido pelo microcotidiano, que os detalhes de manutenção e transformação se efetivam, ou seja, isso 
se dá em uma atividade diária do lavar a roupa no lugar comum ou no espaço domésticoprivado, ou seja, tais procedimentos admitem o "controle minucioso das operações do corpo, que realizam a sujeição constante de suas forças e lhes impõem uma relação de docilidade-utilidade", essas são nomeadas, por ele, de "disciplinas" (FOUCAULT, 2009, p. $71)$.

O corpo é, para ele, uma dada maquinaria do poder, pois ele está submisso e dominado sob a docilidade do discurso disciplinador. Ela provoca uma economia de bonança do capital, mas uma perda nas posições políticas, nas posições de autonomia e liberdade do homem e seu assenhorear de si. O corpo, contudo, é colocado, assim nas mãos do sujeito que tem o poder de mandar em outros, de intervir na modelação a fim de um objetivo específico.

\begin{abstract}
A “invenção" dessa nova anatomia política não deve ser entendida como uma descoberta súbita. Mas como uma multiplicidade de processos muitas vezes mínimos, de origens diferentes, de localizações esparsas, que se recordam, se repetem, ou se imitam, apoiam-se uns sobre os outros, distinguem-se segundo seu campo de aplicação, entram em convergência e esboçam aos poucos a fachada de um método geral (FOUCAULT, 2009, p. 71).
\end{abstract}

Ao demonstrar que a sexualidade e o corpo são assujeitados por essa sociedade que este é fabricado, enquanto construção ideal-racional, e aquele é criado sócioculturalmente - Foucault nos dá instrumentos para desnaturalizar essas convenções, de ousarmos ser diferentes e vermos que sê-lo não é doença ou anormalidade, mas outra forma de viver, compreender o mundo, de amar a si e o outro. Possibilita-nos também desconstruir esses dispositivos sutis de disciplinamente da sexualidade e do corpo ainda presente em algumas instituições como Igreja, Escola, Prisão, dentre outras. Se, para a análise de Foucault, essas não tem na França mais tanta força no século XX, ou seja, o não impacto desses dispositivos institucionalizados como nos séculos antes da secularização desse país. Contudo, ao olharmos a singularidade do Brasil e de suas regiões, mesmo também vivendo esse processo de secularização, essas instituições são expressivas e possuem uma força na sua formação sociocultural, influenciando, assim, boa parte dessa população brasileira². O corpo padrão não se faz no Brasil pelas circunscrições simbólicas que o introjeta em sua perfomatividade cotidiana, mas pelos resquícios de inscritos no corpo que foge ao visível, que adentra aos paradigmas de uma moral cristã, que afirma uma dominação subjetiva. Seria uma "utopia do corpo", categoria pensada por Foucault?

\footnotetext{
${ }^{2}$ Conforme Foucault (2009, p. 72), "técnicas sempre minuciosas, muitas vezes íntimas, mas que têm sua importância: porque definem um certo modo de investimento político e detalhado do corpo, uma nova "microfísica" do poder".
} 
Não estamos remetendo aqui os traços estéticos do corpo, ao desejo do belo e da busca por um corpo sarado por brasileiros(as). Não tratamos sobre a idealização de uma perfeição corporal que move uma indústria farmacêutica que vende essa imagem idealizada, que mantem os que a buscam com remédios, controlam as suas frustrações e obsessões. Não tratamos da fluidez do desejo de amar esse corpo idealizado movedor da indústria pornográfica - que elege esses corpos e suas performatividades para atrair o público - nem tampouco à transgressão dessa indústria da beleza física e das dotações biológicas, pela produção amadora que mostra as estrias, as gorduras localizadas e as multiplicidades de formas corporais pertencentes à nossa realidade.

Verificamos que todos esses são marcas de um corpo que traça singularidades, fazeo imergir na sociedade, que o liga a ela, torna-o social e socializante. Não buscamos o consenso desses corpos, mas como sugere Foucault (1975, p. 01): "não é o consenso que faz surgir o corpo social, mas a materialidade do poder se exercendo sobre o próprio corpo dos indivíduos".

Essas transgressões ao poder do corpo pelo mercado, seja ele estético ou sexual, fazem-se para dar visibilidade que as relações amorosas na vida afetiva das pessoas em sua maioria não se faz por esses corpos idealizados, mantido pelo "investimento do corpo pelo poder" (FOUCAULT, 1975, p. 01). Tal postura para Foucault pode ser pensada como uma reinvindicação sobre o próprio domínio do corpo, de uma assenhorear-se de sua própria estética e desejo. Contudo, nesse transgredir o poder das instituições que buscam dominar o corpo e de ditar seus traços, reinventam dispositivos transformando tais atitudes como positivas ou negativas nas relações subjetivas de quem se submete. Para além, de um corpo preso por valores religiosos e morais que escravizam os desejos, o mercado capitalista torna essas atitudes de procurar o gozo, de sentir as linhas do seu corpo e de encontrá-lo com o toque do outro, como um teste de beleza, o seja, o poder "pode se recuar, se deslocar, investir em outros lugares”, mas “a batalha continua” (FOUCAULT, 1975, p. 01).

Vejamos, por exemplo, as várias secções em que encontram modelos desse objeto de desejo, marcados não pelo físico, mas pelo poder em sua dominação sobre o corpo, enraíza-o e se enaltece a idade, a etnia, os elementos biológicos, os corpos de todos os tipos e estilos, dando-se ênfase as fantasias sexuais que quebram com uma moralidade e instituições que colocam a prática como probidade, como elementos visíveis dessa profundidade. A construção de um conjunto que totaliza um corpo perfeito se faz para além do que Foucault na década de 1970 colocou. Portanto, para ele, naquele período, de um investimento de controle-repressão se passa para um de controle-estimação: "Fique 
nu......mas seja magro, bonito, bronzeado" (FOUCAULT, 1975, p. 02). A sua radicalização transmuta o desejo de uma estética do corpo a partir de uma deliberação do anseio e corroboração do outro, do social e virtual que compõem a sociedade contemporânea.

Essa virtualidade do corpo também se permeia de outras prerrogativas que as ciências atuais, possibilitam a sua mudança visualmente, promovem gestos afirmativos pelas várias curtidas no facebook e comentários nas diversas redes sociais existentes. De um corpo escondido, que põem a sua nudez em quatro paredes, ele se torna elemento de poder, de afirmação e status social em nossa sociedade. O corpo usado para excluir os que não possuem essa idealidade corpórea, para além de um cárcere da alma, como se pensa a filosofia agostiniana, ele passa a ser elemento de afirmação de uma personalidade visual, momentânea e transitória.

Tornam-se marcas de várias temporalidades e experiências. Esse corpo outro que não é físico, e nem espiritual, é, para Foucault, "corpo utópico" e "corpo sem corpo". Mas é visível, aberto e fechado a várias experiências de penetração, de afeto e contato. Esse é de várias formas, maneiras e desejos; move-se pelo nu e desnu, pela erotização e sacralização, um corpo que não se compreende, mas se experimenta e se torna presente, é "um corpo fantasma” (FOUCAULT, 1966, p. 02).

Esse corpo desejante não se submete a sua coisificação, vivi nesse conflito entre o tornar-se objeto e sujeito, o espaço de intervenção e o seu agente. O corpo, para ele, também pode ser um ator utópico quando inscrevemos nele nossos anseios em uma figuração momentânea, por exemplo. Como também no uso de máscaras, que dão brechas para a realização de movimentos e ações não realizadas sem elas, com isso mudam de um espaço real ao imaginado, que o dá elementos de afirmação. Portanto, o corpo possui uma linguagem “enigmática, cifrada, secreta, sagrada” (FOUCAULT, 1966, p. 02). Para ele,

Talvez seria preciso dizer também que fazer o amor é sentir seu corpo se fechar sobre si, é finalmente existir fora de toda utopia, com toda a sua densidade, entre as mãos do outro. Sob os dedos do outro que te percorrem, todas as partes invisíveis do teu corpo se põem a existir, contra os lábios do outro os teus se tornaram sensíveis diante de seus olhos sem-abertos teu rosto adquire uma certeza, há um olhar finalmente para ver tuas pálpebras fechadas. Também o amor, assim como o espelho e como a morte, acalma a utopia do teu corpo, a cala, a acalma, a fecha como uma caixa, a fecha e a sela. É por isso que é um parente tão próximo da ilusão do espelho e da ameaça da morte; e se, apesar dessas duas figuras perigosas que o rodeiam, se gosta tanto de fazer o amor é porque, no amor, o corpo está aqui. (FOUCAULT, 1966, p. 04).

A presentificação do corpo nas relações amorosas se dá pelo toque entre os que as realizam. Para além da certeza da passagem do tempo com o envelhimento do corpo, com 
as suas transformações físicas e simbólicas que o dão visibilidade, a morte e o espelho o revelam para os que estão dispostos em se enfrentar nesse confronto existencial. Contudo, esse aperceber-se movido pela percepção visual, pela falta da vivacidade do corpo em sua atividade cotidiana, pode nos ajudar a olhar as singularidades de seus contornos, de suas brechas e enchimentos artificiais.

Há o toque e a sensibilidade promovida pelo contato entre os corpos, esse produz a sensação do encontro nos espaços escondidos em seu corpo, de uma estimulação em que ele se torna presente, imponderado de animalidade e excitação. Foucault pensa tais prerrogativas de uma presentificação do corpo através do toque, que não busca outro corpo, mas os espaços que o faz movimentar, em que as fantasias agitam a sua realidade não se tem construído os jogos de relações amorosas virtuais. Neles a fantasia se edifica não no encontro de duas pessoas que através de seu contato descobrem os espaços de seu corpo, sentem-no como possuído e possuidor, conhece-o através do outro. Para o amor virtual contemporâneo, o corpo do jogador é movido pela relação saber-poder que não mais se pauta pelo conhecimento dos espaços de prazer do parceiro (a), mas de seu próprio corpo. O não precisar do outro para descobrir esses espaços hoje, promove um sujeito que não busca construir a fantasia em seu próprio corpo, mas projeta-a em seu contato com certos artefatos tecnológicos, que provocam, por sua vez, a sensação de prazer, mas sem o toque do outro.

Enfim, não é essa uma nova maneira de controle do corpo, um novo saber-poder em que se projetam as fantasias que se devem se fazer a dois em um encontro amoroso; não fornecem isso brechas para manter as máscaras de um puritanismo cristão que esconde o desejo carnal e o disciplina em suas relações conjugais, encontrando escape para a sua realização na virtualidade desses jogos; não é o uso da tecnologia uma maneira de produzir determinado prazer, ou seja, induzir fantasias mercadológicas induzidas pelo saber-poder das instituições que as produzem?

\section{CONSIDERAÇÕES FINAIS}

Neste artigo procuramos realizar uma exposição inicial sobre como Foucault pensa o corpo. Percebemos a princípio algumas influencias filosóficos que permeiam suas produções, como Sartre. Destacamos, em suma, que seu diálogo com uma filosofia da transgressão e a sua utilização como um meio de infração dos modelos propagados e defendidos pela filosofia de então. Nietzsche, então é apropriado pelos pensadores no 
“A utopia de um corpo incorpóreo": corpo, poder e saber em Michel de Foucault Assis Daniel Gomes

século XX de diversas formas, mas Foucault utiliza a sua ideia de infração como criação, por exemplo.

Dessa forma, Foucault toma para si a filosofia do diferente, buscando construir uma "ontologia do presente", procura filosofar sobre a fluidez do devir, sobre o homem em seu processo de mudança e alteridade. Enfatizando-o, como forma de desconstruir o forjamento de valores feitos pela maioria das instituições de nossa sociedade, historiciza esse discurso patológico, disciplinador e dócil, e defende o levante do diferente, do outro, que é abafado em meio a esse assenhoramento do corpo. E que esse subordinamento e controle nas minúcias do cotidiano são introjetadas também na formação e criação de uma família e infância. Portanto, o corpo também é inventado, construído e dominado pela relação saber-poder.

Buscamos finalizar nossa reflexão sobre a relação corpo e poder-saber no pensamento de Michel Foucault, fazendo um link com o presente em que vivemos, a sua singularidade e devir. Fomos além de Foucault quando vimos que a marcação do corpo e a busca de espaços de prazer em sua tentativa de tomada de consciência pelo toque do outro, torna-se contemporaneamente substituído pela sensação de prazer promovida pela virtualidade do jogo sexual. A busca de espaços sensíveis pelo atrito da pele, assim, é trocado pelo mecanismo visual de mover imagens que produzam a excitação e gozo. Dominar as relações de prazer não se faz mais pelo saber desses espaços, mas pela construção da fantasia virtual que se dá por meio da separação corporal, de um toque individual e direcionado. Enfim, a descoberta das brechas, dos intervalos e dos lugares sensíveis e eróticos pelo outro no século XXI, torna-se desejante, porém caro, difícil e complexo.

\section{REFERÊNCIAS}

ADVERSE, Helton. O que é "ontologia do presente"? Nuntius Antiquus, Belo Horizonte, n. 6, p. 129-152, dez. 2010. Disponível em: < http://www.periodicos.letras.ufmg.br/index.php/nuntius antiquus/article/viewFile/209 1/2038>. Acesso em: 20 jun. 2016.

BARROS, Roberto. Nietzsche, Foucault e a biopolítica: uma análise imoral do estado da política. In: ALMEIDA, José Carlos Silva de; BARROS, Fernando R. de M. (Org.). Filosofia e cultura. Fortaleza: Edições UFC, 2011. p. 253-270.

COMTE, Auguste. Curso de filosofia positiva. São Paulo: Abril Cultural, 1978.

DURKHEIM, Émile. As regras do método sociológico. São Paulo: Martins Fontes, 2007. 
“A utopia de um corpo incorpóreo": corpo, poder e saber em Michel de Foucault

ERIBON, Didier. Michel Foucault, 1926-1984. São Paulo: Companhia das Letras, 1990.

FERNÁNDEZ-ARMESTO, Felipe. Verdade: uma história. Rio de Janeiro: Record, 2000.

FOUCAULT, Michel. Vigiar e punir: o nascimento da prisão. Rio de Janeiro: VOZES, 2009.

FOUCAULT, Michel. Poder-corpo. Entrevista de junho de 1975, p. 01-05, 1975.

FOUCAULT, Michel. O corpo utópico. In: FOUCAULT, Michel. El cuerpo utópico. Las hetorótopias. Espanha: Ed. Nueva Vision, 2010 [1966]. p. 01-04.

FOUCAULT, Michel. As palavras e as coisas: uma arqueologia das ciências humanas. São Paulo: Martins Fontes, 2002.

FOUCAULT, Michel. História da sexualidade: a vontade de saber. São Paulo: Paz \& Terra, 2014.

FOUCAULT, Michel. História da sexualidade: o uso dos prazeres. São Paulo: Paz \& Terra, 2014.

FOUCAULT, Michel. História da sexualidade: o cuidado de si. São Paulo: Paz \& Terra, 2014.

GABBI JR., Osmyr Faria. Uma análise de Malabie Mentale et personalité de Foucault. In: MONTENEGRO, Maria Aparecida P.; PINHEIRO, Clara Virgínia de Q.; AZEVEDO JÚNIOR, Ivânio Lopes de (Org.). Natureza e linguagem na filosofia. Fortaleza: Edições UFC, 2008. p. 449-480.

HOBBES, Thomas. Leviatã. São Paulo: Nova Cultura, 1997.

KANT. Resposta à pergunta: “Que é o Iluminismo?”. Tradução de Artur Morão, 2000. p. $1-12$.

NIETZSCHE, Friedrich. Obras incompletas. São Paulo: Nova Cultura, 1999.

ROUSSEAU, Jean-Jacques. Os pensadores. São Paulo: Abril Cultural, 1973.

SARTRE, J-P. Os pensadores. São Paulo: Abril Cultural, 1978.

TEMPLE, Giovana Carmo. Acontecimento, poder e resistência em Michel Foucault. Cruz das Almas/Bahia: UFRB, 2013.

VEYNE, Paul. Foucault: seu pensamento, sua pessoa. Rio de Janeiro: Civilização Brasileira, 2011.

WILLIAMS, James. Pós-estruturalismo. Rio de Janeiro: Vozes, 2013. 